\title{
LABOUR MIGRATION FROM UKRAINE UNDER THE GLOBAL ECONOMIC TURBULENCE
}

\author{
Olexandr Shnyrkov', Valerii Mazurenko², Roman Stakanov ${ }^{3}$
}

\begin{abstract}
The purpose of the article is to analyse the trends of labour migration from Ukraine under the global economic crisis caused by COVID-19. The subject of the research is international labour migration in Ukraine. The study should predict the consequences of the coronavirus crisis for labour migration and place of Ukraine in the world labour market in the nearest future. Methodological basis of the research comprised the list of theoretical and empirical methods of research; there was provided the analysis of recent research publications subject under the discussion, compared the results obtaining with statistical data, suggested the practical recommendations that were received on the base of survey results. Researches in a number of OECD countries have found that the risk of infection among migrants is at least two times higher as among locals. The number of international migrants is declined in 2020 for the first time in recent history, as the number of new migrants slows down and re-emigration rates substantially increased. Ukraine has the highest rates of permanent immigrants among European countries. In 2019, there was among approximately 5 million people of foreign origin in Ukraine, the largest migration groups were from Belarus, Kazakhstan, Moldova, Russia, and Uzbekistan. At the same time, Ukraine ranked 8th in the world and 2nd in Europe for emigration in 2019. Ukraine was the largest country of origin of refugees in Europe amounted to 93 thousand people at the end of 2018. In 2019, as in previous decades, the largest migration corridors in Europe were in Ukraine, including the Russia-Ukraine and Ukraine-Russia corridors, which held the first positions in the volume of migration in this part of the world. The military conflict in the East of Ukraine has strengthened the current trend towards reorienting of Ukrainian migration to the West. The employment structure of Ukrainian labour migrants is mostly inefficient, as only $26.8 \%$ of Ukrainian workers are employed abroad according to the qualifications obtained. The COVID-19 pandemic has affected virtually all spheres of public life; it has affected emigration from Ukraine, a crucial factor of which has been the introduction of lockdown in key host countries of Ukrainian labour migration, in particular, in the EU. However, the existence of an unconditional demand for Ukrainian workers in the labour-importer countries has led to the solution of problems with access of workers in an ad hoc manner in the first half of 2020, in particular, through the organization of workers transportation from Ukraine for seasonal work. The results of the study have shown that despite the fact that the structure of permanent migration from Ukraine is dominated by migration to the Russian Federation, trends in long-term and especially in temporary labour migration since 2014 and until now, clearly indicate a change in the vector of labour movement towards the EU. Labour emigration is not able to solve the problem of Ukraine's economic development; it just solves the task of maintaining the welfare of the migrant families and provides the opportunities to develop the human capital of migrant children, primarily through funding by means of migration capital their education in Ukraine. Analysis of the current global and national economic situation, regulatory measures, both in Ukraine and in the countries of migration destination, which directly or indirectly affect migration flows, indicates that in the medium term we cannot predict that the COVID-19 pandemic will significantly affect large-scale labour migration.
\end{abstract}

Key words: labour migration, Ukraine, crisis, remittances, COVID-19, lockdown.

JEL Classifications: F22, L26, F22, F22, F02

\footnotetext{
Corresponding author:

${ }^{1}$ Taras Shevchenko National University of Kyiv, Ukraine.

E-mail: aisch@ukr.net

ORCID: https://orcid.org/0000-0001-8437-5210

${ }^{2}$ Taras Shevchenko National University of Kyiv, Ukraine.

E-mail: mvi1210@ukr.net

ORCID: https://orcid.org/0000-0002-7167-215X

${ }^{3}$ Taras Shevchenko National University of Kyiv, Ukraine.

E-mail: roman.stakanov@gmail.com

ORCID: https://orcid.org/0000-0003-3412-8451
} 


\section{Introduction}

International labour migration fell into a state of catastrophic crisis due to the new pandemic of COVID-19, while showing the sharp increase in history in early 2020. The lockdown has significantly affected international migration, which has become a fundamental and important component of the globalized economy. Governments around the world have closed their borders and severely restricted people's mobility in an attempt to stem the spread of the new virus. However, these measures were largely limited in stopping the spread of cross-border containment, but they had a significant negative impact on the global economic dynamics.

The processes of international labour migration, the effectiveness of national, regional and global levels of its regulation have been discussed in the economic literature for a long period of time. It is important to consider how the world labour market is being transformed under the influence of the processes of digitalization, virtualization and robotization of the world economy. However, the COVID-19 pandemic had a significant impact on both the structure and development, as well as on future trends in international labour migration and migration policy transformation.

These issues are especially relevant for small open economies, such as Ukraine, which are significantly dependent both on the global economic situation and on trends in labour migration and remittances to the country, which affect the FX market stability and the national economy as a whole. The study should answer to the above questions, as well as predict the consequences of the coronavirus crisis for labour migration and place of Ukraine in the world labour market in the nearest future. Theoretical and empirical research methods are used in the work, which involves the analysis of recent research publications, comparison of the results with statistical data, as well as aggregation of the data in the form of practical recommendations to national and international regulatory institutions.

\section{Literature review}

The issue of labour market research is the subject of long-term interest for scientists. Classical economists (Adam Smith, David Ricardo) based their approach on the opportunity for the market to ensure the full use of labour resources and rejected government intervention in the economy. Neoclassicists (A. Marshall, A. Pigou, M. Friedman) highlighted the study of human capital and with the respect to knowledge as a driver of labour market and economic development in general, as well as the issuance of money as the only factor that can indirectly stimulate employment. They drew attention to the study of human potential and great importance to knowledge as a driver of the labour market development and the economy in general, and the currency issue as the only factor that may indirectly encourage employment. Keynesian theory (J.M. Keynes) focuses on government regulation of the labour market, and employment is a function of an effective demand, the lack of which can lead to sharp production decrease and, consequently, to higher unemployment.

Neoclassical synthesis (P. Samuelson) (Ryazantsev, Tkachenko, 2010) argues for the need to combine approaches of market and state regulation of labour markets focusing on unemployment as a trend. Concept study of the international labour market allows to expand the consideration of modern theories of international migration. E. Ravenstein (Ravenstein, 1989) formulated the 11 basic laws of migration in 1885 , which later grounded for further study of the trends international labour migration. We can highlight the following statements that remain relevant for modern international labour migration:

- the main reason for migration is economics. Even when formally labour migration is not explicitly declared, the real reason for the international movement is employment. Furthermore, regardless of the initial type of migration, the country of origin will have an impact on the labour market and the social system of the destination country.

- migration is a more significant factor in the growth of large cities than natural population growth (and this idea can also be extended to the mechanism of population growth in most developed countries);

- the scale of migration increases with the development of transport, trade, industry;

- migration mainly takes place over short distances (despite technological development, intra-regional migration is currently predominant in absolute terms, it accounts for $60 \%$ of the total international migration).

Neoclassicalapproach (R.Böhning,J.Simon) (Adepoju, 2000; Böhning, 1972) argues that international migration flows as a derivative of regional differences in income and wages, as well as imbalances in labour supply and demand in different parts of the world. Synthetic theory of migration (D. Massey) (Massey et al, 1993) determines international labour migration by globalization of the labour market and the formation of migration networks, when the migration vector is determined primarily by the migration direction to regions where there are already established significant diasporas. The social capital allows to substitute the lack of physical capital and reduce the transaction costs of migration.

The concept of migration systems (M. Kritz, L. Lim, G. Zlotnik) (Kritz et al, 1992) argues that the international migration trends are not permanent, but largely influenced by the geographical factors, and migration itself forms a single migration system. It includes countries of origin and destination countries 
between which the interdependence of asymmetric nature is formed. The concept of migration systems correlates with the phenomena of regionalization and regional economic integration acting as a trigger of formation of regional labour markets. In the 21 st century, the key focus of migration research has shifted to the 1) migrant integration models; 2 ) the impact of migration on economic development at the national, regional and global levels; 3 ) the development of migrants themselves (Ivakhnyuk, 2016). Much of the academic research of international organizations, in particular the OECD and the World Bank, focuses on the second area of research. Taking into account not only purely quantitative characteristics of welfare (such as income, wages) in determining the motivation of international migration is important for understanding the development factors of the international labour market. Thus, A. Deaton (Deaton, 2013) argues that the society cannot be assessed using only living standards indicators, but a welfare should be evaluated as a whole a set of indicators: 1) the material well-being (income, wealth, GDP per capita); 2) physical and psychological well-being (life expectancy, health standards, the level of happiness); 3) quality of education, 4) participation in public life.

Although the COVID-19 pandemic is a new factor influencing the world economy as a whole and international labour migration in particular, its impact has been extensively studied in a number of research papers. Thus, A. Khanna notes (Khanna, 2020) that the recession caused by COVID-19 may have more serious consequences for the global labour market than that which the world faced during the crisis of 2009. The ILO estimates that up to 25 million people could become unemployed worldwide due to the impact of COVID-19, with estimates ranging from the 5.3 million by "low-scenario" job losses and the 24.7 million - by "high-scenario" (ILO, 2020). The impact of the crisis, as in the case of the 2008 recession, may vary by country. During the peak of COVID-19 in Wuhan, almost 5 million people in China lost their jobs in January and February 2020 (Cheng, 2020). Angus Reid Institute survey found that $44 \%$ of Canadian households lost their jobs (Macleans, 2020), about 900,000 workers lost their jobs in Spain in mid-March 2020 (Keeley, 2020). In March 2020, more than 10 million US workers lost their jobs and addressed for the state aid.

\section{Global migration context}

Long-term trends in international migration show that migration is largely associated with global economic, social, political and technological transformations that affected wide range issues of global political agenda. The growing scale of international migration takes place in accordance with the current development of the global economy, the number of international migrants, according to $\mathrm{UN}$ and ILO estimates is almost 272 million people (UN DESA, 2019) (in 2000, this figure was 150 million people (World Bank, 2020a). The majority of people emigrate for reasons related to employment, family reunification and education. Almost two-thirds of the world's international migration (164 million people) is workers.

The COVID-19 pandemic has caused global health problems, which in turn has led to an economic and social crisis that could potentially result in the largest recession in the world economy since the end of World War II. Travel restrictions, lockdowns and social distancing measures introduced in response to COVID-19 substantially decreased the quality of life of the world's population. According to World Bank estimates (World Bank, 2020b), from 88 to 115 million people fall into poverty due to the deep economic crisis. Also, the availability of work does not protect against income loss during the crisis. According to the International Labour Organization data (ILO, 2020b), global workers' incomes fell by $10.7 \%$ during the first three quarters of 2020 compared to the same period in 2019. The estimated revenue losses amounted to 3.5 trillion USD or $5.5 \%$ of world GDP. According to latest World Bank forecasts, the current crisis will exacerbate the problem of poverty, causing the reduction in global per capita income by 3.6 percent, leading to an increase in the number of people living below the poverty level by 70-100 millions of people (Kondratenko, 2021).

The crisis caused by COVID-19 had unprecedented impact for migration flows. Prior to the pandemic constant migration flows to the OECD countries amounted to 5.3 million people in 2019, similar figures amounted to 5 million migrants in 2017 and 2018 . After the pandemic almost all OECD countries have restricted visits for foreigners, the issuance of new visas and residence permits decreased by $46 \%$ in OECD countries in the first half of 2020 compared to the same period in 2019, which was the largest decrease in the history. The decline was $72 \%$ in the second quarter of 2020, and overall immigration in 2020 resulted in a historical minimum for international migration to the OECD (Huddleston, 2015). Migrants, especially those in low-paid jobs, may be both more affected by the economic consequences of the pandemic and more vulnerable to the COVID-19 in countries where the pandemic is spreading.

As of September 4, 2020, immigrants from the 20 countries with the highest number of COVID-19 cases accounted for almost 32\% of the total number of international migrants, and they transferred $37 \%$ of all remittances to their countries of origin in 2019 (Cheng, 2020). For example, the oil-producing countries of the Gulf Cooperation Council (GCC) are an important for immigration from South Asia and East 
Africa. Since many migrant workers in GCC countries returned to their countries of origin or were no longer able to get to work due to lockdown, this drastically reduced their income and, as a result, the ability to send money to their families in their countries of origin. Thus, the global economic crisis, as well as falling oil prices in the GCC countries reduced remittance flows to sub-Saharan Africa and South Asia in 2020 by $23 \%$ and $22 \%$, respectively (World Bank, 2020a).

Migrants' transfers rose from 126 billion USD in 2000 to the expected 666 (World Bank, 2020b) or 689 billion (World Bank, 2020a) in 2020, remittances to low- and middle-income countries reached a record 554 billion USD in 2019, surpassing the volume of FDI to these countries for the same period. In 2019, the top five recipients of migration capital were India ( 83.1 billion), China (68.4 billion), Mexico (38.5 billion), the Philippines ( 35.2 billion) and Egypt (26.8 billion) (World Bank, 2020a). Remittance flows to low- and middle-income countries fell on 19.7 percent to 445 billion USD due to the economic crisis caused by the COVID-19 pandemic in 2020, which meant a decrease in wages and employment for migrant workers.

The number of international migrants is declined in 2020 for the first time in recent history, as the number of new migrants slows down and re-emigration rates substantially increased. International migrant workers suffered from the pandemic, both as a result of their significant involvement in the direct process of countering the spread of COVID-19 and because of their significant vulnerabilities, such as living conditions and poverty. Researches in a number of OECD countries have found that the risk of infection among migrants is at least two times higher as among locals. However, the further development of migration policy under crisis, its differentiation and emphasis on the problems of migrant integration will be important in the short term to achieve a sustainable inclusive global economic recovery. A more inclusive approach to migration policy in a wide range of related areas leads to sustainable results of migrant integration.

\section{Migration profile of Ukraine}

It is recommended to use the data from international organizations, expert assessments, as well as indirect forms of analysis, and the inward remittances dynamics in the study of labour emigration in Ukraine. Gaps in the state system of migration estimation illustrates the fact that, the volume of overseas labour migration, according to official data from the State Employment Center for 2020, totals to 86.3 thousand people (State Employment Center, 2021). However, according to the UN, Ukraine has the highest rates of permanent immigrants among European countries, along with Germany, Russia, the United Kingdom and Poland. In 2019, among approximately 5 million people of foreign origin in Ukraine the largest migration groups were from Belarus, Kazakhstan, Moldova, Russia and Uzbekistan (UN DESA, 2019). At the same time, Ukraine ranked 8 th in the world and 2nd, after Russia, in Europe for emigration in 2019.

In 2019, as in previous decades, the largest migration corridors in Europe were in Ukraine, including the Russia-Ukraine and Ukraine-Russia corridors, which held the first positions in the volume of migration in this part of the world. After the beginning of RussianUkrainian military conflict in 2014, Ukraine faced a new phenomenon of increasing the number of internally displaced persons (IDPs). Ukraine ranked 13th in the world and 2nd in Europe, after Turkey, with a figure of 800 thousand IDPs in 2018. The motivation of internal displacement by military conflict distinguishes the migration of IDPs in Ukraine from the rest of Europe, where the motives for such displacement are originated natural disasters.

Although IDPs could potentially be seen as an additional catalyst for the economic development of the host regions by increasing social activity, opening new businesses by internal migrants, and interest in carrying out the work vacancies for which there is no demand from local residents, these benefits are not used in Ukraine, while there are no application of such a large-scale human resource in the country. The military conflict in the East of Ukraine has strengthened the current trend towards reorienting of Ukrainian migration to the West (Table 1).

Ukraine was the largest country of origin of refugees in Europe amounted to 93 thousand people at the end of 2018. A large share of refugees from Ukraine went to the Russian Federation. According to the UN High Commissioner for Refugees (UNHCR, 2019), about 400,000 people have moved to Russia since the beginning of the military conflict in 2014, some of whom have received refugee status or temporary

Table 1

EU/Russia migration comparison for Ukrainian emigration

\begin{tabular}{|c|c|c|c|c|c|c|}
\hline & \multicolumn{2}{|c|}{ Migration, million persons } & \multicolumn{2}{|c|}{ Remittance, million USD } & \multicolumn{2}{c|}{ Remittance, share in total, in per cent } \\
\hline & 2012 & 2017 & 2015 & 2019 & 2015 \\
\hline EU & 0.603 & 0.901 & 3397 & 7725 & $48.8 \%$ & 64.8 \\
\hline Russia & 0.511 & 0.341 & 1835 & 1266 & $26.4 \%$ & 10.6 \\
\hline
\end{tabular}

Source: compiled by the authors on the basis (National Bank of Ukraine, 2017a, 2017b, 2020) 
asylum, as well as Russian citizenship, without renouncing from Ukrainian.

Given the pan-European negative trend of population decline, some European countries have reached the most favourable regulatory environment for attracting workers from like-mended countries, as evidenced by the example of Ukrainian labour migration to Poland. The fastest growth rate of migration was observed in 2014-2017, when in 2017 alone Poland issued 660 thousand residence permits, of which $85 \%$ were received by Ukrainian labour migrants (Eurostat, 2018).

The employment structure of Ukrainian labour migrants is mostly inefficient, as only $26.8 \%$ (State Statistics Service of Ukraine, 2018) of Ukrainian workers were employed abroad according to the qualifications obtained in 20015-2017, and 36.1\% were employed in non-skilled vacancies at all. The share of those who worked in a specialty or position that required higher qualifications was significantly higher in the United States (58.3\%), Russia (43.6\%) and the Czech Republic (40.3\%) and significantly decreases in Poland - to $16.4 \%$.

In contrast to most other labour force exporters, Ukraine is characterized by a negative demographic trend. Ukraine, like other European countries, shows a trend in the increase of the elder population, however, due to the economic factor, it has a more significant natural population decline, multiplied by permanent net emigration with a significant rate of temporary emigration.

The negative trend of labour resources could be seen in Ukraine in the 21 st century. Every year the population of Ukraine is reduced by 170-180 thousand (Mirror Weekly, 2017). Only due to natural population decline, our country is among the countries with the highest dynamics of population decline in the world. The traditional problems of natural population reduction and irreversible migration in the late 20th - early
21 st century (due to which the number of economically active population of Ukraine decreased by almost 1 million people) were sophisticated by the problem of Russian military aggression, as a result of which Ukraine lost another 3 million economically active citizens, which together resulted in a $22 \%$ of cumulative reduction of national labour force in the 21 st century.

The demographic forecast of the number of Ukrainian citizens is at the rate of 32-35 million in 2050 (IOM, 2016), and up to 28 million according to the UN average forecast in 2100 (Figure 1), given the growing share (up to $50 \%$ ) of the population aged over 60 , lack of a balanced migration and macroeconomic policy threatens the national security of Ukraine under the demographic crisis (United Nations, 2017).

The population of Ukraine will decline according to the basic and pessimistic UN forecasts, as can be seen from Figure 1, and according to the optimistic forecast, population growth will start with a mark of 40 million people only after 2075 . Under such circumstances, the need to attract additional labour from abroad in the medium and long term seems inevitable, which involves the development of effective immigration policy, the best practices of countries using supply-driven and synthetic migration policy systems (for instance, Canada and Australia).

According to the State Tax Service of Ukraine, 11.8 million potentially active citizens were absent in the database in 2020, they did not receive any income at all, and 4.1 million citizens of Ukraine in the controlled territory are invisible on the tax map of Ukraine, since they did not perform any action of paying taxes (Economic truth, 2020). According to the State Statistics Service, 3.4 million people worked in Ukraine without official registration in January-March 2020. $20.6 \%$ of the total employed population aged from 15 to 70 worked without an official employment. Of the

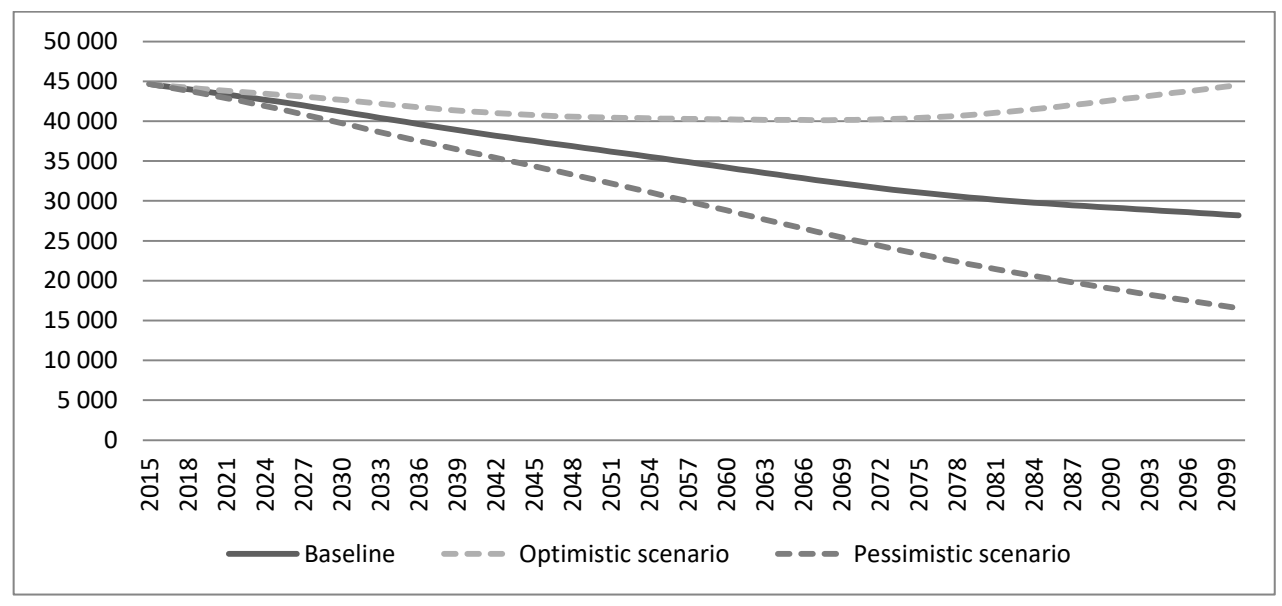

Figure 1. Forecast of population change in Ukraine in 2015-2100

Source: compiled by the authors on the basis (United Nations, 2017) 
total unofficially employed 1.35 million are women and 2 million are men.

External labour migration is an important component of the economic security for Ukraine. According to the methodology of the Ministry for Development of Economy, Trade and Agriculture of Ukraine (Ministry for Development of Economy, Trade and Agriculture of Ukraine, 2013), the integrated index of economic security consists of 9 indices (130 separate indicators), of which $43 \%$ (55 indicators) are directly or indirectly affected by international migration. Thus, according to the index, $71 \%$ of sub-indices of demographic security depend on migration, foreign economy $-45 \%$, investment and innovation $-71 \%$, macroeconomic $-75 \%$, food $73 \%$, social $-67 \%$, financial $-22 \%$.

To determine the importance of money transfer from migrants for the national economic situation, it is necessary to consider their impact on the balance of payments of Ukraine. The balance of payments of the Ukraine has been in an unstable position for a long period of time. The current account in Ukraine mostly has a stable deficit since 2006 (National Bank of Ukraine, 2017a). Money transfers of migrants coming to Ukraine through correspondent accounts of banks, international payment systems, as well as informal channels, are one of the key factors that keep the balance of payments from stronger fluctuations. The volume of remittances to Ukraine in the period after 2008 shows a steady increase in absolute terms, while showing a steady rate in relative terms (ranging from 7.5 to $8.5 \%$ of GDP since 2015) (Table 2). Unlike other indicators of foreign economic activity, remittances are much less dependent on domestic and foreign economic fluctuations, they tend to be counter-cyclic. Also, in contrast to the global trend of declining remittances, the inflow of migration funds to Ukraine has remained stable in the pandemic time.

As can be seen from Table 1, Ukraine received 12.1 billion USD as private money transfers in 2020 compared to 11.9 billion in 2019 . At the same time, according to the National Bank of Ukraine, 4.7 billion USD was transferred through informal channels in
2020 (Holubov, 2021). The role of remittances for the Ukrainian economy in general, and for the balance of payments in particular, is constantly growing. If in absolute terms the income from migrants is significantly lower than the income from the export of goods ( 12.1 billion and 49.3 billion, respectively), the relative share of migrant revenues is becoming increasingly important. During the 2008-2020 the volume of remittances increased by $96 \%$, and the volume of exports decreased by $24 \%$ over the same period (from 66.9 to 49.3 billion USD).

It should also be noted, that the official data of the National Bank of Ukraine on money transfers may be understated. Thus, according to the World Bank (World Bank, 2020a), their volume in 2019 amounted to 15.788 billion USD, and the share of remittances in GDP in 2016-19 varied between 10-11\% (World Bank, 2020a). At the same time, despite the differences in absolute indicators, the tendency to increase the absolute amounts of remittances and its importance for the stability of the national economy is obvious.

However, migrants wishing to be involved in the process of financing long-term local infrastructure projects (22\% of their total (IOM, 2016)) do not have an institutional mechanism to realize their aspirations. Although migrants heavily interested in investing in the development in small and medium business in Ukraine in construction, trade and industry, which generally intersects with the investment priorities of foreign investors in Ukraine, confirming the feasibility of considering migrant revenues as potential migration capital in Ukraine, given that the public authorities provide the necessary conditions for investment.

Although it has its own specifics associated with a high degree of "revenue shadowing", the problem of efficient use of migrant remittances, is generally not separated from the comprehensive need to improve the investment climate in Ukraine. We consider macroeconomic efficiency being in need for reforms in tax, pension, and monetary systems, education and science financing, innovation, transparency in the distribution of funds and the provision of benefits to business.

Table 2

Dynamics of private money transfers to Ukraine, million USD

\begin{tabular}{|l|c|c|c|c|c|c|c|c|c|c|c|}
\hline & 2008 & 2011 & 2012 & 2013 & 2014 & 2015 & 2016 & 2017 & 2018 & 2019 & $2020^{*}$ \\
\hline Total revenue & 6177 & 7019 & 7526 & 8537 & 6489 & 6959 & 7535 & 9264 & 11111 & 11921 & 12099 \\
\hline Salary & 3024 & 4022 & 4619 & 5652 & 4318 & 4116 & 4794 & 6269 & 7911 & 8907 & 8796 \\
\hline Private transfers & 3153 & 2997 & 2907 & 2885 & 2171 & 2843 & 2741 & 2995 & 3200 & 3014 & 3325 \\
\hline $\begin{array}{l}\text { Volumes of remittances } \\
\text { in \% to GDP }\end{array}$ & 3.4 & 4.1 & 4.1 & 4.5 & 4.8 & 7.6 & 8.1 & 8.2 & 8.5 & 7.7 & 8.3 \\
\hline
\end{tabular}

* - preliminary data

Source: compiled by the authors on the basis (National Bank of Ukraine, 2017a, 2017b, 2020) 


\section{Migration transformation under the COVID-19 pandemic}

The COVID-19 pandemic has affected virtually all spheres of public life; it affected emigration from Ukraine, a crucial factor of which was the introduction of lockdown in key host countries of Ukrainian labour migration, in particular, in the EU.

However, the existence of an unconditional demand for Ukrainian workers in the labour-importer countries has led to the solution of problems with access of workers in an ad hoc manner in the first half of 2020, in particular, through the organization of workers transportation from Ukraine for seasonal work. Charter flights with employees from Ukraine to Poland, the Czech Republic, Germany, Austria, Finland, the United Kingdom, Finland, and Israel were organised. The Italian government has decided to grant a temporary residence permit for a period of 6 months to agricultural workers and those who are working in households. Canada has exempted key categories of migrant workers from entry restrictions when its borders have been closed to foreigners. The Portuguese government has decided to provide rapid regularization to all immigrants whose residence permit applications were already pending. The UK has extended visas for around 2,800 health workers (doctors, nurses and paramedics) and their families (International Trading Centre, 2020).

While in Ukraine there was limited re-emigration during spring of 2020 about 500,000 migrants returned to the country, mostly those with shortterm contracts), but its scale was not as significant as expected. This is particularly confirmed by the amounts of migrants remittances, which decreased in March-April 2020 compared to 2019 by $8 \%$ (from 1.892 to 1.748 billion USD) (Libanova, 2020), however, as it is shown in Table 2, they entered the growing trend by the end of the year. 1.27 million citizens of Ukraine lived in Poland as the largest recipient of Ukrainian labour migration in January 2020. This figure has been relatively stable since March 2019. Poland experienced a lockdown due to the COVID-19 epidemic in March-April 2020, but only $15 \%$ of Ukrainian migrant workers returned to Ukraine, and in May the number of Ukrainian workers in Poland increased again (Radio Liberty, 2020). At the same time, long-term Ukrainian migrants who have either permanent residence permits in the EU countries or the citizenship of labour-importing countries tended to stay abroad and limit or cancel their arrival to Ukraine.

It is estimated that 400-500 thousand migrants who temporarily returned to Ukraine with the beginning of the pandemic make up about one-fifth of the permanent migration pool (2.5-3 million) of labour emigrants from Ukraine (World Bank, 2020a).
Then they either already returned to the countries of employment or do so in a favourable economic environment in close future.

A key factor, which continues to be the determining motivation for emigration, is the significant wage difference between Ukraine and the EU countries. As of January, 1, 2021, 21 of the 27 EU Member States set a national minimum wage. Thus, the monthly minimum wage is usually below 700 EUR in the eastern EU countries and more than 1,500 EUR in the north-west of the EU (Eurostat, 2021). In January 2021 minimum wage was: Bulgaria (332 EUR), Hungary (442 EUR), Romania (458 EUR), Latvia (500 EUR), Croatia (563 EUR), the Czech Republic (579 EUR), Estonia (584 EUR), Poland (614 EUR), Slovakia (623 EUR), and Lithuania (642 EUR) (Eurostat, 2021). In comparison, the minimum wage in Ukraine in January, 1, 2021 increased to 173 Euros, which is almost twice less than in Bulgaria and more than 3.5 times less than in Poland (National Bank of Ukraine, 2021; Verkhovna Rada, 2020).

The global labour market, transformed under the influence of digitalization and robotization, has received a new vector of development due to the corona crisis. During recent years migration processes have become increasingly interconnected with the development of technology and innovation. Some new trends in the labour market, such as distance working, are gradually becoming the workers way of life. A layer of social migrants is formed: they live in one country, but being employed and receive salary from abroad. However, they are completely immersed in the social environment of other regions, gain skills in multinational and multicultural teams. All these trends are quite typical for the virtual labour market in Ukraine. Thus, the growth of the IT sector in Ukraine continued despite the crisis.

It can be argued, given the current structure of labour migration from Ukraine, including the prevailing employment in sectors that require manual labour of migrants, that the trends, which are important for the national and global labour market on virtualization of migration, will not significantly affect the dynamics and the structure of labour emigration from Ukraine in the medium term.

\section{Conclusions}

Despite the fact that the structure of permanent migration from Ukraine is dominated by migration to the Russian Federation, trends in long-term and especially in temporary labour migration since 2014 and until now, clearly indicate a change in the vector of labour movement towards the EU (especially to Poland). The employment structure of Ukrainian workers remains low skilled (and employment in the fields of construction, work in households and agriculture still prevailing), and the change in the migration vector does 
not improve the quality of overseas employment of workers from Ukraine.

Absolute numbers of remittances and their relative values in relation to GDP have been growing in Ukraine in recent years in full accordance with their countercyclical nature and, in general, structure of money transfers correlates with key countries of migration destination (increasing role of the EU countries, and reduction of Russia). The stability of migration flows under current circumstances in the Ukrainian economy can be considered a relatively positive phenomenon, however, the short-term advantage could transform into a strategic defeat and the final loss of ties with the homeland of most of the Ukrainian citizens abroad. Permanent emigration from Ukraine is especially vulnerable under the projected change in the population of Ukraine by 2100 , according to the basic and pessimistic scenario of which in our country there will be a sharp fell in the population and labour force.

Labour emigration is not able to solve the problem of Ukraine's economic development; it just solves the task of maintaining the welfare of the migrant families and provides the opportunities to develop the human capital of migrant children, primarily through funding by means of migration capital their education in Ukraine.

Under the reduction, stagnation or minimal recovery of Ukrainian economy, the departure of the active labour force is able to suspend the degradation of the socio-economic environment in the country. However, in long term perspective in Ukraine, as well as in other European countries, growing share of elderly people is a stable negative demographic trend, which is aggravated by economic, political and military problems, and both temporary and permanent departure of labour will lead to the loss of a key resource of the country - human capital, and, as a result, will leave no chances for the implementation of the Ukrainian "prosperity" development project as well as slowdown of economy's rate of development.

Analysis of the current global and national economic situation, regulatory measures, both in Ukraine and in the countries of migration destination, which directly or indirectly affect migration flows, indicate that in the medium term we cannot predict that the COVID-19 pandemic will significantly affect largescale labour migration. The issue of the dynamics of this process is largely related to the prospects for economic recovery in the EU, and consequently, the demand for labour from Ukraine. A significant advantage in this case is the geographical proximity of our country to a key importer of migrant workers, which allows, if necessary, to quickly react on the shortage of workers in the EU in the case of a dynamic improvement in the economic regional trends.

\section{References:}

Adepoju, A. (2000). Issues and recent trends in international migration in Sub-Saharan Africa. International Social Science Journal, 383-394. Retrieved January 23, 2021, from: http://onlinelibrary.wiley.com/doi/10.1111/14682451.00267/abstract

Bilgili, Ö., Huddleston, T., \& Joki, A.-L. (2015). The Dynamics between Integration Policies and Outcomes: A Synthesis of the Literature. Barcelona Centre for International Affairs and Migration Policy Group, 2015. Retrieved January 23, 2021, from: https: / / fr.scribd.com/document/271339269/MIPEX-Literature-Review-theDynamics-BetweenIntegration-Policies-and-Outcomes-1

Böhning, R. (1972). The Migration of Workers in the United Kingdom and the European Community. Oxford University Press. Retrieved January 23, 2021, from: https://www.cambridge.org/core/journals/journal-of-socialpolicy/article/bohning-w-r-the-migration-of-workers-in-the-united-kingdom-and-the-european-communityoxford-university-press-for-the-institute-of-race-relations-london-1972-xvi167-pp-300/646C90F63A8202A5BF E727C4A2B36584

Cheng, E. (2020). Roughly 5 million people in China lost their jobs in the first 2 months of 2020 // CNBC. Available at: https://www.cnbc.com/2020/03/16/china-economy-millions-lose-their-jobs-as-unemploymentspikes.html

Davidson, P. (2020). Unemployment could top 32\% as $47 \mathrm{M}$ workers are laid off amid coronavirus: St. Louis Fed // USA Today. Retrieved January 23, 2021, from: https://www.usatoday.com/story/money/2020/03/30/ coronavirus-unemployment-could-top-32-47-million-lose-jobs-fed-says/5091156002/

Deaton, A. (2013). The Great Escape: Health, Wealth and the Origins of Inequality. Princeton University Press, Princeton, New Jersey, 360.

Economic truth (2020). The head of the tax service: more than 4 million people do not systematically pay taxes. Retrieved January 23, 2021, from: https://www.epravda.com.ua/news/2020/12/20/669367/

Eurostat (2018). Residence permits for non-EU citizens. Retrieved January 23, 2021, from: https://ec.europa.eu/ eurostat/documents/2995521/9333446/3-25102018-AP-EN.pdf/3fa5fa53-e076-4a5f-8bb5-a8075f639167

Eurostat (2021). Disparities in minimum wages across the EU. February 05, 2021. Retrieved January 23, 2021, from: https://ec.europa.eu/eurostat/en/web/products-eurostat-news/-/ddn-20210205-1

Holubov, A. (2021). In 2020 Ukraine received a record amount of remittances. Deutsche Welle, Ukrainian edition. Retrieved January 23, 2021, from: https://p.dw.com/p/3ofCn 
Huddleston, T. (2015). Migrant Political Participation: A Review of Policies and Integration Results in the OSCE Region. Research Paper, Organization for Security and Co-Operation in Europe, Office for Democratic Institutions and Human Rights, Warsaw.

International Labour Organization (ILO) (2020a). COVID-19: Protecting workers in the workplace. Press Release. Retrieved January 23, 2021, from: https://www.ilo.org/global/about-the-ilo/newsroom/news/WCMS_738742/ lang-en/index.html

International Labour Organization (ILO) (2020b). ILO Monitor: COVID-19 and the World of Work, Sixth Edition // Briefing note, ILO, Geneva, 2020. Retrieved January 23, 2021, from: https://www.ilo.org/global/ topics/coronavirus/impacts-and-responses/WCMS_755910/lang--en/index.htm

International Organization for Migration (IOM) (2016). Migration as an enabler of development in Ukraine. Kyiv. 2016. Retrieved January 23, 2021, from: http://www.iom.org.ua/sites/default/files/iom_migration_as_an_ enabler of development in ukraine.pdf

International Organization for Migration (IOM). (2016). Migration in Ukraine: Facts And Figures. Retrieved January 23, 2021, from: http://www.iom.org.ua/sites/default/files/ff_eng_10_10_press.pdf

International Trading Centre (2020). Labour migration at the time of COVID-19. Retrieved January 23, 2021, from: https://www.itcilo.org/stories/labour-migration-time-covid-19

Ivakhnyuk, I. V. (2016). Development of migration theory in the context of globalization. Retrieved January 23, 2021, from: https://www.socionauki.ru/journal/files/vg/2016_1-2/026-043.pdf (in Russian)

Keeley, G. (2020). Spain sees historic rise in unemployment as nearly 900,000 lose jobs since coronavirus lockdown. The Independent. Retrieved January 23, 2021, from: https://www.independent.co.uk/news/world/ europe/spain-coronavirus-lockdown-unemployment-job-loss-update-a9442146.html

Khanna, A. (2020). Impact of Migration of Labour Force due to Global COVID-19 Pandemic with Reference to India. doi: 10.1177/0972063420935542

Kondratenko, M. (2021). World Bank: coronavirus crisis - the deepest since World War II. Deutsche Welle, Ukrainian edition. Retrieved January 23, 2021, from: https://p.dw.com/p/3dSRh

Kritz, M., Lim, L. L., \& Zlotnik, H. (1992). International migration systems: a global approach. Oxford: Clarendon Press. 345 p. Retrieved January 23, 2021, from: http://journals.sagepub.com/doi/pdf/10.1177/ 030913259301700429

Libanova, E. M. (2020). Labor migration from Ukraine: the impact of COVID-19. Retrieved January 23, 2021, from: http://www.nas.gov.ua/UA/Messages/Pages/View.aspx?MessageID=6547

Macleans (2020). COVID-19: Canada layoff tracker. Retrieved January 23, 2021, from: https://www.macleans.ca/ economy/covid-19-canada-layoff-tracker/

Massey, D., Arago, J., \& Hugo, G. (1993). Theories of International Migration: A Review and Appraisal. Population and Development Review, no. 19, pp. 431-466.

Ministry of Economic Development and Trade of Ukraine (2013). On approval of Methodical recommendations for calculating of the level of economic security of Ukraine. № 1277. Retrieved January 23, 2021, from: http://cct.com.ua/2013/29.10.2013_1277.htm (in Ukrainian)

Mirror Weekly (2017). Kinakh A. There is no future without people. Retrieved January 23, 2021, from: https://dt.ua/macrolevel/bez-lyudey-nemaye-maybutnogo-259099_.html (in Ukrainian)

National Bank of Ukraine (2017a). Private money transfers. Retrieved January 23, 2021, from: https://bank.gov.ua/doccatalog/document?id=19208355

National Bank of Ukraine (2017b). Private money transfers. Retrieved January 23, 2021, from: https://bank.gov.ua/doccatalog/document?id=19208357

National Bank of Ukraine (2020). Dynamics of the balance of payments (since 1998). Retrieved January 23, 2021, from: http://www.bank.gov.ua/control/uk/publish/category?cat_id=44464

National Bank of Ukraine (2020). Private money transfers. Retrieved January 23, 2021, from: https://bank.gov.ua/ files/ES/Perekaz_m.pdf

National Bank of Ukraine (2021). The official exchange rate of hryvnia to foreign currencies on 01.01.2021. Retrieved January 23, 2021, from: https://bank.gov.ua/ua/markets/exchangerates?date $=01.01 .2021 \&$ period=daily

Radio Liberty (2020). Thousands of Ukrainians live in Poland, but are they returning home? Retrieved January 23, 2021, from: https://www.radiosvoboda.org/a/ukrayintsi-v-polshchi/31083623.html (in Ukrainian)

Ravenstein, E. G. (1989). The laws of migration. Journal of the Statistical Society, vol. 52(2), pp. 241-305.

Ryazantsev S. V., \& Tkachenko M. F. (2010). World labor market and international migration. Retrieved January 23, 2021, from: http://www.vipbook.pro/nauka-i-ucheba/ekonomika/78957-ryazancev-sv-tkachenkomf-mirovoy-rynok-truda-i-mezhdunarodnaya-migraciya.html (in Russian)

Sergii Sardak, Roman Stakanov and Liydmila Shvorak (2020). Concept of comprehensive enterprises business model in global economic environment. Academy of Entrepreneurship Journal, vol. 26(2), pp. 1-6.

Stakanov, R. (2016). Influence of immigrants on the entrepreneurship development in the host countries. Baltic Journal of Economic Studies, vol. 2, no. 4, pp. 73-78. doi: 10.30525/2256-0742/2016-2-4-73-78 
Stakanov, R. (2018). The role of regional migration policy in the development of migration processes. Scientific Journal. Economics, Management and Sustainability, vol. 3, issue 1, pp. 70-78.

State Employment Centre (2021). Retrieved January 23, 2021, from: https://www.dcz.gov.ua/analitics/67

State Statistics Service of Ukraine (2018). External labor migration of the population of Ukraine 2015-2017. Retrieved January 23, 2021, from: http://www.ukrstat.gov.ua/druk/publicat/kat_u/publ11_u.htm

State Statistics Service of Ukraine (2021). Retrieved January 23, 2021, from: http://www.ukrstat.gov.ua/

UN DESA (2019). International Migrant Stock 2019. Population Division, New York. Retrieved January 23, 2021, from: https://www.un.org/en/development/desa/population/migration/data/estimates2/estimates19.asp

UNHCR (2019). Russian Federation. Retrieved January 23, 2021, from: https://reporting.unhcr.org/ node/2551?y=2019\#year

United Nations (2017). The 2017 Revision of World Population Prospects. Retrieved January 23, 2021, from: https://esa.un.org/unpd/wpp/

Verkhovna Rada (2020). Law of Ukraine “On the State Budget of Ukraine for 2021” of 15.12.2020 № 1082-IX. Retrieved January 23, 2021, from: https://zakon.rada.gov.ua/laws/show/1082-20\#Text

Weissmann, J. (2020). 6.6 Million Americans filed for unemployment last week. Retrieved January 23, 2021, from: https://slate.com/business/2020/04/unemployment-jobs-numbers-economy-coronavirus.html

World Bank (2020a). Migration and Development Brief 32: COVID-19 Crisis Through a Migration Lens, April. Washington, DC.

World Bank (2020a). Personal remittances, received (current US\$) - Ukraine. Retrieved January 23, 2021, from: https: / /data.worldbank.org/indicator/BX.TRF.PWKR.CD.DT?locations=UA

World Bank (2020b). Personal remittances, received (\% of GDP) - Ukraine. Retrieved January 23, 2021, from: https://data.worldbank.org/indicator/BX.TRF.PWKR.DT.GD.ZS?locations=UA

World Bank (2020b). Phase II COVID-19 Crisis through a Migration Lens. Retrieved January 23, 2021, from: https: / / www.knomad.org/sites/default/files/2020-10/Migration\%20\%26\%20Development\%20Brief\%20 33\%20-\%20October\%202020.pdf 